\title{
PEMBERDAYAAN MASYARAKAT DALAM PENGELOLAAN DAN PENINGKATAN NILA GUNA SAMPAH DI KELURAHAN NGLETIH KECAMATAN PESANTREN KOTA KEDIRI
}

\author{
Ekawati Wasis Wijayati ${ }^{1}$, Marianingsih ${ }^{2}$ \\ ${ }^{1}$ Prodi Kesehatan Masyarakat, Fakultas Ilmu Kesehatan \\ ${ }^{2}$ Prodi Keperawatan, Fakultas Ilmu Kesehatan \\ ${ }^{1,2}$ Institut Ilmu Kesehatan Bhakti Wiyata Kediri \\ Email: ekawati.wasis@gmail.com
}

\begin{abstract}
Waste generated needs to be managed appropriately to be avoided due to negativity from waste. The Urban people Ngletih generally do waste management by means of traditional and simple by means of collected was then burned. But in fact was not solve the problems but also dangerous for the environment. The purpose of community service is to educate and empower the community in an effort to increase the value of waste by making compost and ecobrick. The activity carried out is to provide counseling to the public about waste and simulating making compost from garbage and making ecobrick from inorganic (plastic) waste. The results of statistical analysis with Wilcoxon-Test showed the value of $p=0,000$ ( $p<0.05)$, which means the mean difference between the scores of knowledge before and after counseling about waste. Helps suggest what has been done has been successful in increasing respondents' knowledge about waste. In an effort to reducing the volume of waste, then needs to be sustainable counseling in order to raising awareness and participation.
\end{abstract}

Keywords: Kelurahan Ngletih, Waste Management, organic waste, inorganic waste

\begin{abstract}
Abstrak. Sampah yang dihasilkan perlu dikelola dengan tepat untuk menghindari dampak negatif dari sampah. Masyarakat kelurahan Ngletih umumnya melakukan pengelolaan sampah dengan cara tradisonal dan sederhana yaitu dengan cara dikumpulkan kemudian dibakar. Namun cara tersebut bukan menyelesaikan masalah tetapi juga berbahaya bagi lingkungan. Tujuan dari pengabdian kepada masyarakat ini adalah memberikan edukasi serta pemberdayaan masyarakat dalam upaya meningkatkan nilai guna sampah dengan pembuatan kompos dan ecobrick. Kegiatan yang dilakukan adalah dengan memberikan penyuluhan pada masyarakat tentang sampah dan simulasi pembuatan kompos dari sampah organik serta pembuatan ecobrick dari sampah anorganik (plastik). Hasil analisa statistik dengan uji beda menunjukkan nilai $\mathrm{p}=0,000(\mathrm{p}<0,05)$ yang berarti bahwa ada perbedaan rerata yang bermakna antara skor pengetahuan sebelum dan setelah dilakukan penyuluhan tentang sampah. Sehingga penyuluhan yang telah dilakukan berhasil meningkatkan pengetahuan responden tentang sampah. Dalam upaya pengurangan volume sampah, maka perlu dilakukan penyuluhan secara berkesinambungan guna menumbuhkan kesadaran dan partisipasi masyarakat.
\end{abstract}

Kata kunci: Kelurahan Ngletih, Pengelolaan Sampah, Sampah Organik, Sampah Anorganik

\section{PENDAHULUAN}

Sampah merupakan salah satu masalah yang banyak dihadapi masyarakat. Permasalahan terkait dengan sampah merupakan permasalahan yang rumit karena banyak pihak yang terlihat dalam hal tersebut. Tantangan dalam penanganan masalah sampah adalah kesadaran masyarakat terkait kebiasaan membuang sampah dan memilah sampah sesuai jenisnya. Ibu-ibu rumah tangga dalam kegiatannya dapat dipastikan menghasilkan sampah baik sampah organik maupun sampah anorganik. Sampah yang dihasilkan tersebut biasanya hanya dibakar atau dibuang begitu saja.

Sampah adalah barang sisa atau buangan yang sudah tidak digunakan dan tidak terpakai lagi. Umumnya, sampah dibedakan menjadi sampah organik dan sampah anorganik. Sampah organik merupakan sampah yang berasal dari makhluk hidup (manusia, binatang, tumbuhan) yang mengalami pelapukan dan mudah membusuk. Sampah jenis ini dapat terurai oleh bakteri secara alami dan cepat. Sedangkan sampah anorganik adalah sampah yang berasal 
dari sisa kegiatan manusia yang tidak dapat membusuk dan sulit terurai oleh bakteri sehingga membutuhkan waktu relatif panjang untuk dapat terurai (Fadillah dkk, 2019).

Berdasarkan informasi yang diperoleh dari beberapa warga kelurahan Ngletih terkait dengan lingkungan adalah masalah pengelolaan sampah. Dari hasil wawancara dan pengamatan dapat diketahui bahwa umumnya masyarakat kelurahan Ngletih melakukan pengelolaan sampah dengan cara tradisonal dan sederhana. Pengelolaan sampah yang umum dilakukan oleh masyarakat kelurahan Ngletih dengan cara sampah dikumpulkan pada suatu tempat kemudian dibakar. Tanpa masyarakat sadari bahwa cara tersebut bukan menyelesaikan masalah tetapi justru menimbulkan masalah baru yaitu menjadi sumber pencemaran lingkungan. Melihat hal tersebut, penanganan sampah terutama sampah rumah tangga idealnya perlu keterlibatan masyarakat sebagai penghasil sampah tersebut. Pada prinsipnya, masyarakat memiliki potensi dan kontribusi yang besar dalam pengelolaan sampah (Fadillah, 2019).

Mengingat dampak sampah yang berbahaya bagi kesehatan dan lingkungan, perlu dilakukan penanganan masalah sampah dengan tepat. Upaya mengurangi dan menangani masalah sampah perlu dilakukan dengan suatu sistem pengelolaan yang berkesinambungan dan menyeluruh (Kurniati dkk, 2019).

Sebagai tindakan awal yang dapat dilakukan adalah dengan memberikan edukasi pada masyarakat terkait dengan wawasan dan kesadaran masyarakat dalam pengelolaan sampah. Agar edukasi yang dilakukan efektif, maka diperlukan keterlibatan aktif dari masyarakat sasaran. Dengan adanya kegiatan kemasyarakatan seperti arisan, pengajian, Karang Taruna, Posyandu, PKK merupakan suatu potensi yang bermanfaat untuk menjadi sarana/ media edukasi. Berdasarkan kondisi tersebut, dan informasi dari beberapa masyarakat kelurahan Ngletih yang menyampaikan belum pernah ada edukasi terkait pengelolaan sampah, maka masyarakat kelurahan Ngletih perlu diberikan edukasi tentang pengelolaan sampah untuk mengatasi malasah lingkungan dan diharapkan juga dapat meningkatkan nilai guna sampah.
Tujuan kegiatan pengabdian kepada masyarakat ini adalah memberikan edukasi pada masyarakat tentang pengelolaan sampah. Melalui penyuluhan dan simulasi/praktek pengelolaan sampah dalam bentuk pembuatan kompos dan ecobrick, diharapkan dapat meningkatkan peran serta masyarakat dalam pengelolaan sampah sehingga dapat meningkatkan nilai guna sampah serta mengurangi volume sampah.

\section{METODE PELAKSANAAN}

Kegiatan pengabdian kepada masyarakat ini dilakukan dengan cara memberikan penyuluhan terkait sampah yaitu jenis sampah dan pemilahan sampah berdasarkan jenisnya. Selain penyuluhan, juga dilakukan simulasi/ praktek/demonstrasi pengelolaan sampah secara sederhana yaitu pembuatan ecobrick dari sampah anorganik (sampah plastik) dan kompos dari sampah organik. Sasaran dalam kegiatan tersebut adalah ibu-ibu PKK kelurahan Ngletih sebanyak 38 orang. Kegiatan pengabdian kepada masyarakat tersebut dilaksanakan pada tanggal 27 Agustus 2019 bertempat di Balai Pertemuan Kelurahan Ngletih.

Kegiatan pengabdian kepada masyarakat ini terbagi dalam dua sesi kegiatan. Sesi pertama adalah pemberian penyuluhan tentang sampah. Sebelum diberikan materi tentang sampah, ibuibu yang hadir diminta untuk mengisi angket yang berisi pertanyaan seputar sampah dan cara pengolahannya. Hal ini dilakukan untuk mengetahui pemahaman tentang sampah sebelum dilakukan penyuluhan. Selanjutnya diberikan penyuluhan terkait sampah meliputi: pengertian dan jenis-jenis sampah; sumber sampah; paradigma dalam pengelolaan sampah; serta metode pengelolaan sampah. Pada sesi ini juga dilakukan diskusi dan tanyajawab dengan ibu-ibu peserta.

Dilanjutkan dengan sesi kedua yaitu simulasi/praktek/demonstrasi pembuatan kompos dari sampah organik dan ecobrick dari sampah anorganik terutama sampah plastik. Setelah pembuatan kompos dan ecobrick, ibu-ibu yang hadir kembali diminta untuk mengisi angket.

Evaluasi pada kegiatan pengabdian kepada masyarakat ini terutama dilakukan untuk melihat keberhasilan kegiatan penyuluhan tentang 
sampah. Prinsip penyuluhan adalah upaya edukasi terhadap masyarakat yang bertujuan untuk merubah pengetahuan. Untuk mengetahui adanya perubahan pengetahuan, maka evaluasi terhadap kegiatan penyuluhan tentang sampah dilakukan dengan melihat skor pengetahuan dari pretest dan posttest yang diuji secara statistik. Evaluasi dilaksanakan dengan memberikan angket di awal kegiatan (pretest) dan diakhir penyuluhan (posttest). Angket yang diberikan berisi pertanyaan-pertanyaan terkait materi penyuluhan tentang sampah. Hasil skor angket dianalisis secara statistik dengan uji beda untuk mengetahui adanya perbedaan skor pengetahuan antara sebelum dan setelah penyuluhan. Metode ini digunakan sebagai parameter keberhasilan kegiatan pengabdian kepada masyarakat terutama penyuluhan. Bila ada peningkatan skor posttest dari skor pretest, maka pelaksanaan penyuluhan dapat dikatakan berhasil meningkatkan pengetahuan tentang sampah.

\section{HASIL DAN PEMBAHASAN}

Pengabdian kepada masyarakat ini terdiri dari dua kegiatan yaitu penyuluhan tentang sampah dan simulasi/praktek/demonstrasi pengolahan sampah secara sederhana dengan pembuatan kompos dari sampah organik dan ecobrick dari sampah anorganik (sampah plastik). Hasil dari kegiatan tersebut adalah sebagai berikut:

\section{Penyuluhan Tentang Sampah}

Sebelum diberikan materi tentang sampah, ibu-ibu yang hadir diminta untuk mengisi angket yang berisi pertanyaan seputar sampah dan cara pengolahannya. Hal ini dilakukan untuk mengetahui pemahaman tentang sampah sebelum dilakukan penyuluhan. Perbedaan hasil pretest dan posttest terhadap pemahaman responden yang dilakukan sebelum penyuluhan dan setelah pemberian materi penyuluhan dapat dilihat pada gambar 1.

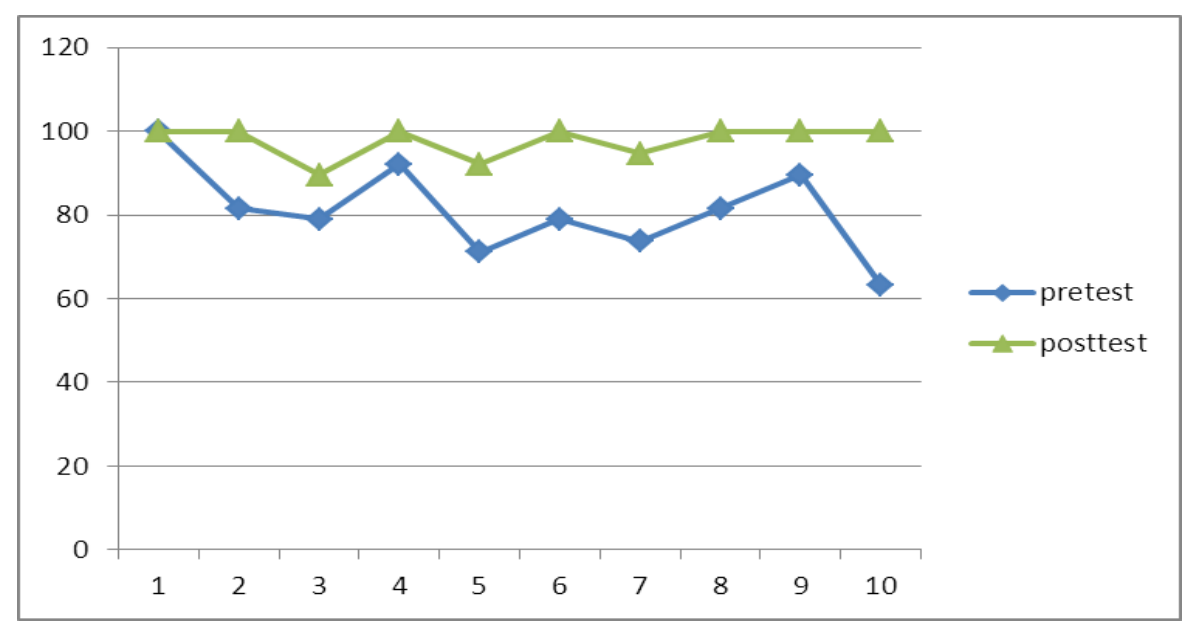

Gambar 1. Perbandingan Pemahaman Tentang Sampah Sebelum dan Setelah Penyuluhan

Berdasarkan gambar 1. Dapat diketahui bahwa pemahaman responden paling rendah $(63,16 \%)$ terlihat pada pengelolaan sampah anorganik menjadi ecobrick. Menurut responden, pada prinsipnya mereka mengetahui tentang jenis dan cara pengelolaan sampah, namun mereka belum mempraktekkan apa yang telah mereka ketahui. Hal tersebut dapat saja terjadi karena di wilayah kelurahan Ngletih masih tersedia lahan relatif luas sehingga memungkinkan sampah ditampung selanjutnya dibakar. Selain itu, masyarakat juga belum banyak yang mengetahui manfaat dari pengolahan sampah dan cara untuk melakukan pengolahan sampah terutama sampah skala rumah tangga. Setelah diberi penyuluhan, maka hasil posttest menunjukkan ada peningkatan pemahaman responden terhadap sampah meliputi jenis sampah, pemilahan sampah, maupun cara pengelolaan sampah terutama pengolahan menjadi kompos dan ecobrick. Hal tersebut menunjukkan telah terjadi peningkatan pengetahuan responden setelah diberikan penyuluhan tentang sampah. Skor ratarata pengetahuan sebelum dan setelah penyuluhan dapat dilihat pada tabel 1 . 
Tabel 1. Hasil Evaluasi Pengetahuan Responden Tentang Sampah Sebelum dan Setelah Penyuluhan

\begin{tabular}{lccc}
\hline \multicolumn{1}{c}{ Skor Pengetahuan } & Rata-rata & N & Sig. \\
\hline Skor pengetahuan pretest & 8,11 & 38 & 0,000 \\
Skor pengetahuan posttest & 9,76 & 38 & \\
\hline
\end{tabular}

Berdasarkan tabel 1. dapat diketahui ratarata skor pengetahuan sebelum penyuluhan (pretest) adalah 8,11 dan rata-rata skor pengetahuan meningkat menjadi 9,76 setelah dilakukan penyuluhan (posttest). Hasil analisa statistik dengan uji beda Wilcoxon menunjukkan nilai $\mathrm{p}=0,000(\mathrm{p}<0,05)$ yang berarti bahwa ada perbedaan rerata yang bermakna antara skor pengetahuan sebelum dan setelah dilakukan penyuluhan tentang sampah. Sehingga dapat dikatakan bahwa penyuluhan yang telah dilakukan berhasil meningkatkan pengetahuan responden tentang sampah.

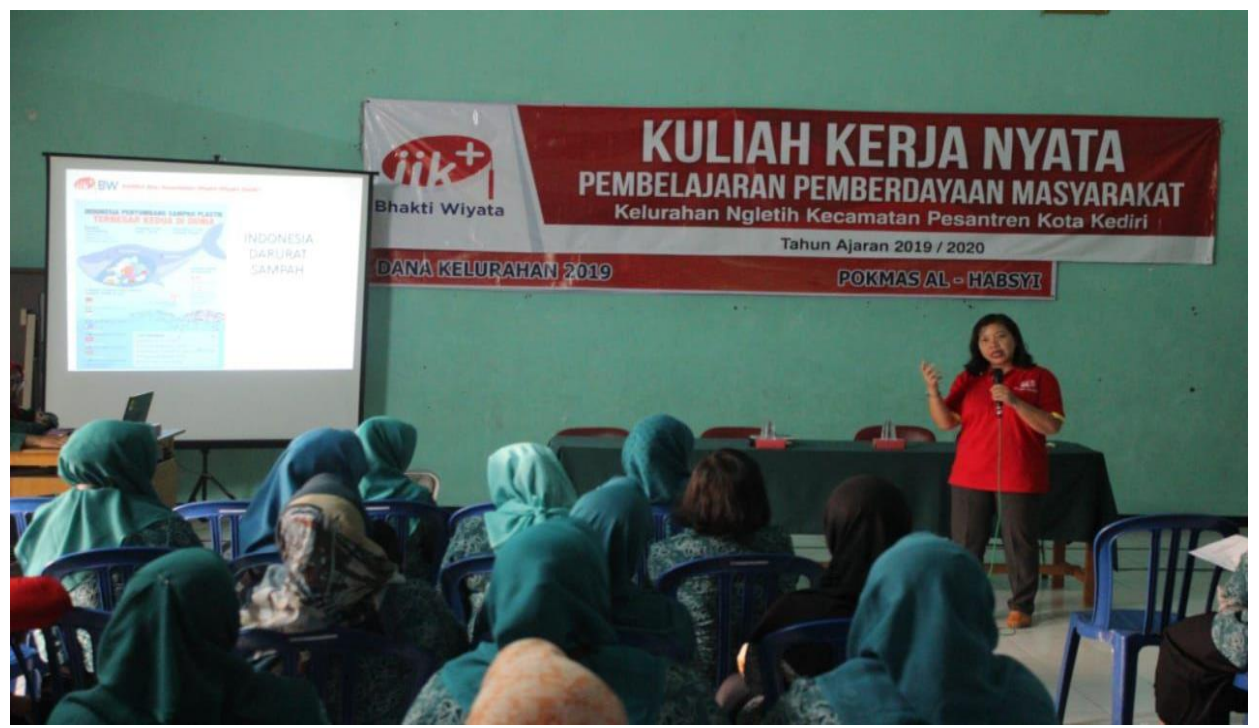

\section{Gambar 2. Penyampaian Materi Penyuluan Tentang Sampah Pada Ibu-Ibu PKK}

Dengan diberikannya penyuluhan tentang sampah, masyarakat terutama ibu-ibu PPK sasaran penyuluhan menjadi paham akan pentingnya pengelolaan sampah. Diharapkan setelah mengikuti penyuluhan tersebut, responden dapat mengolah sampah yang dihasilkan dari aktivitas rumah tangga sehari-hari baik secara perseorangan maupun kelompok. Dengan mengolah sampah secara tepat, maka dapat menyelamatkan lingkungan dari bahaya sampah.

2. Simulasi/Praktek/Demonstrasi Pembuatan Kompos dan Ecobrick

Kegiatan berikutnya pada pengabdian kepada masyarakat ini adalah praktek pengelolaan sampah organik menjadi kompos dan sampah anorganik menjadi ecobrick. Prinsip pembuatan kompos dan ecobrick ini adalah memanfaatkan sampah yang dihasilkan dari aktivitas sehari-hari di rumah tangga. Pembuatan kompos yang dilakukan adalah dengan metode keranjang Takakura dengan memanfaatkan barang-barang bekas yang sudah tidak terpakai. Metode tersebut dipilih karena mudah dilakukan dan cocok untuk skala rumah tangga. Kompos adalah hasil fermentasi atau dekomposisi dari bahan-bahan organik dengan mikroorganisme sebagai aktivator (Cundari, 2019). 


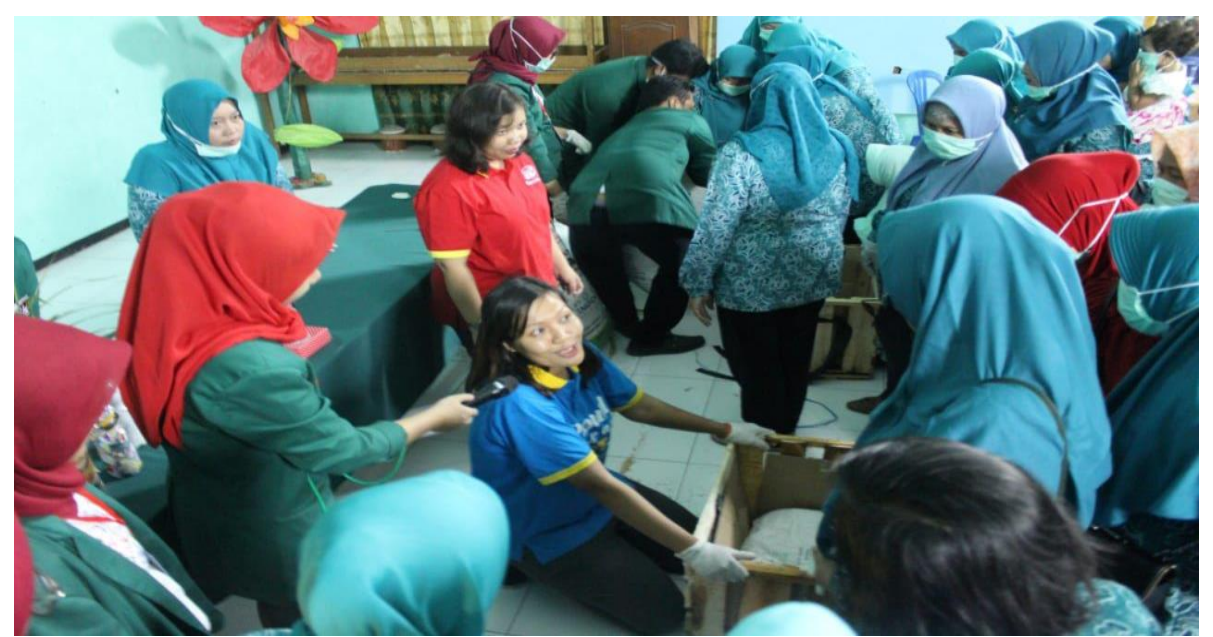

Gambar 3. Simulasi Pembuatan Kompos Dari Sampah Organik Rumah Tangga

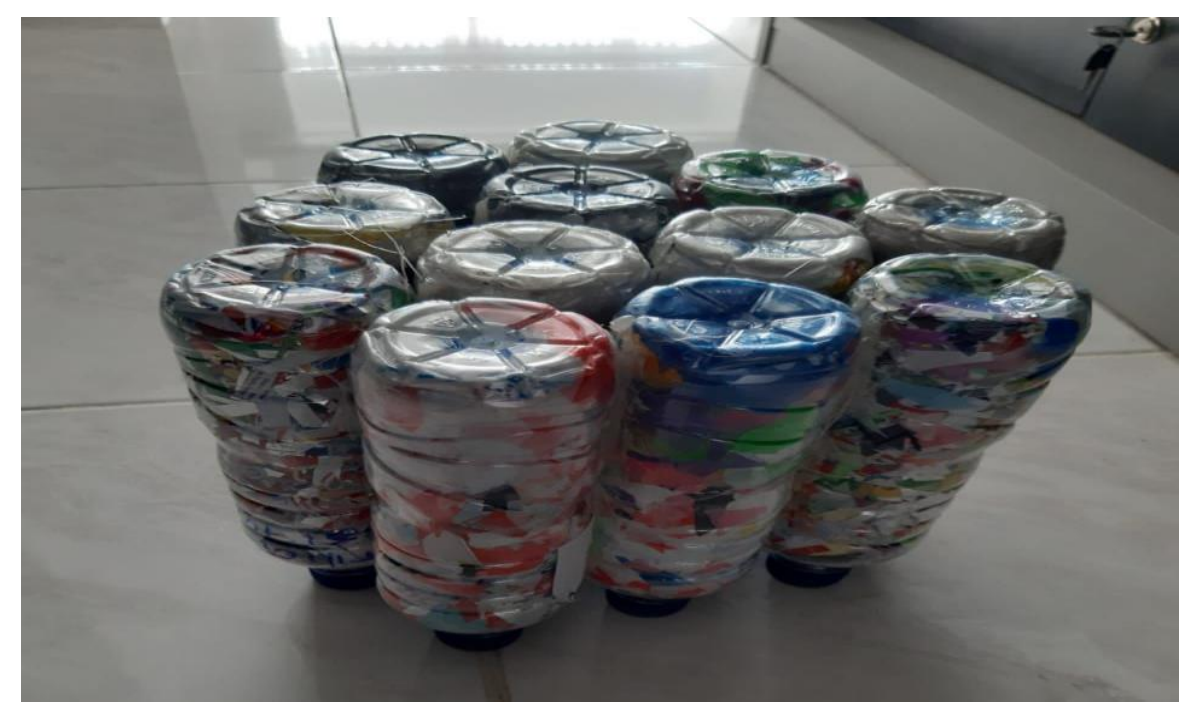

Gambar 4. Hasil Pembuatan Ecobrick

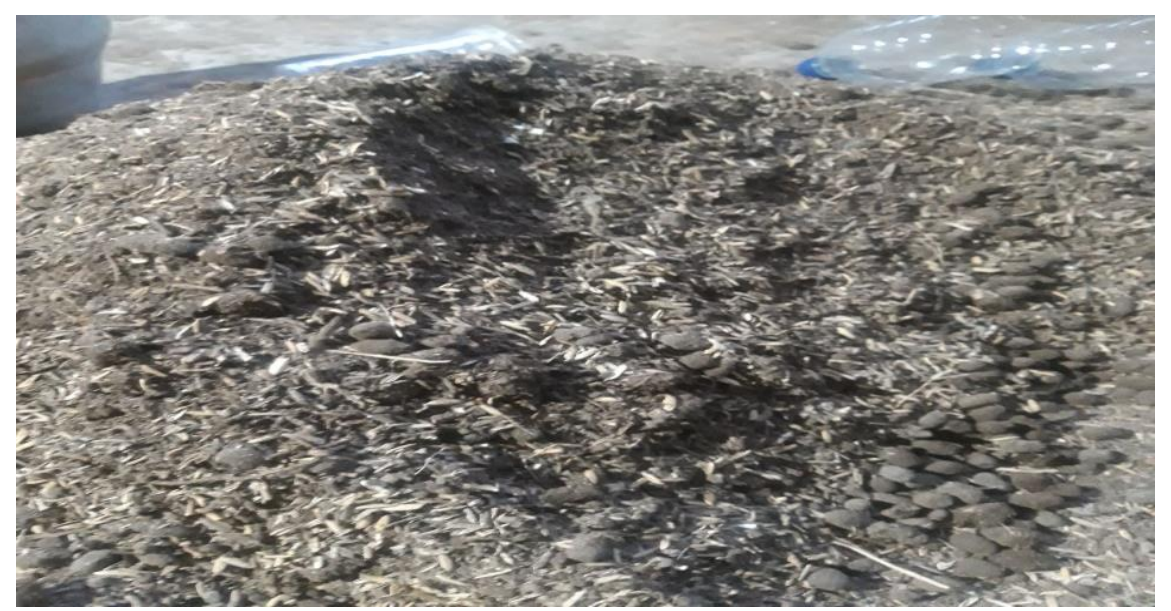

Gambar 5. Hasil Kompos Dari Sampah Organik Rumah Tangga

Kompos dibuat dari sampah organik rumah tangga yang mudah membusuk berupa sisa makanan, sayuran, buah-buahan, daun dan bahan lain yang mudah membusuk. Alat pengomposan yang digunakan merupakan alat sederhada yang mudah didapat dan dibuat sendiri. Proses pembuatan kompos adalah sebagai berikut:

1. Siapkan peti bekas kemasan buah kemudian bagian dalam peti yaitu dasar dan samping peti lapisi dengan kardus bekas 
2. Letakkan bantal sekam di dasar peti (berfungsi untuk menyerap air, mengurangi bau dan mengontrol udara agar mikroba berkembang dengan baik)

3. Isi dasar peti dengan starter/kompos jadi secukupnya (hal ini berfungsi sebagai starter proses pengomposan karena di dalamnya terkandung mikroba pengurai)

4. Selanjutnya masukkan sampah (sampah sebelum dimasukkan peti harus dipotong kecil-kecil, semakin kecil ukuran akan semakin cepat terurai), proses memasukkan sampah dapat dilakukan setiap hari. Adukaduk sampah setiap selesai memasukkan bahan-bahan yang akan dikomposkan

5. Untuk mempercepat pengomposan, dapat ditambahkan/disemprotkan EM4. Masukkan EM4 kedalam alat penyemprot/ sprayer (untuk mempermudah penggunaannya). EM4 disemprotkan secukupnya (tidak kering ataupun terlalu basah) campuran tersebut setiap kali akan mengaduk sampah yang baru dimasukan. Jika terlalu basah dapat tambahkan sekam

6. Selanjutnya masukan bantal sekam dan kemudian tutupi mulut peti dengan kain tiham/gelap

7. Kemudian tutuplah tutup rapat-rapat agar serangga dan lalat tidak masuk

8. Sampah yang baru dimasukkan akan difermentasi dalam 1-2 hari

9. Lakukan kegiatan tersebut berulang-ulang sampai peti terisi penuh

10.Bahan yang telah menjadi kompos akan berwarna hitam, tidak berbau dan tidak becek.

Untuk sampah anorganik terutama sampah plastik didaur ulang menjadi ecobrick agar dapat dimanfaatkan kembali. Ecobricks adalah teknik mengolah sampah plastik menjadi sebuah benda yang bermanfaat. Kegiatan ini dapat membantu mengurangi menumpuknya sampah plastik. Cara pembuatan ecobrick adalah sebagai berikut:

1. Kumpulkan plastik bekas kemasan, cuci sampai bersih dan keringkan (untuk memudahkan proses pembuatan, gunting kecil-kecil plastik yang berukuran besar)

2. Siapkan botol plastik bekas, cuci bersih dan keringkan
3. Masukkan plastik kemasan bekas ke dalam botol plastik

4. Kemudian dipadatkan hingga mengisi semua ruang botol

5. Timbang untuk memastikan bahwa botol telah terisi sesuai standar yaitu kurang lebih 200 gr untuk botol ukuran $600 \mathrm{ml}$

6. Botol plastik yang sudah terisi tersebut selanjutnya dapat dirangkai sesuai kebutuhan menjadi barang bermanfaat.

Dengan mendaur ulang sampah plastik menjadi ecobrick banyak manfaat yang diperoleh, antara lain menyelamatkan lingkungan dari pencemaran limbah plastik. Botol hasil ecobrick yang sudah terkumpul nantinya dapat disusun, dirangkai, dan disatukan sedemikian rupa dengan bantuan perekat berupa lem kaca, yang nantinya bisa dibentuk menjadi produk sederhana seperti bangku, kursi, meja. Ecobrick juga dapat menjadi bata ramah lingkungan yang dapat dimanfaatkan untuk berbagai kebutuhan, misal pembatas di taman.

Dalam kegiatan simulasi/ praktek/ demonstrasi, ibu-ibu PKK terlibat aktif berpartisipasi selama proses kegiatan. Hal ini dilakukan agar ibu-ibu tersebut dapat lebih memahami proses pembuatan kompos dan ecobrick sehingga dapat membuat kompos dan ecobrick dari sampah yang dihasilkan dari aktivitas rumah tangga sehari-hari baik secara perseorangan maupun kelompok. Dengan dilakukannya simulasi/ demonstrasi/ praktek tersebut ibu-ibu akan memiliki pengetahuan dan kemampuan dalam pengelolaan sampah dengan memanfaatkan sampah yang dihasilkan dari aktivitas rumah tangga setiap hari sekaligus dapat mengedukasi anggota rumah tangga terutama anak-anak untuk menjaga kebersihan rumah dan lingkungan dari pencemaran sampah (Mulasari, 2018).

Partisipasi masyarakat sangat diperlukan dalam upaya mengurangi/ mereduksi volume sampah mulai dari sumbernya. Pengelolaan sampah yang direncanakan dengan baik, dapat mendatangkan pemasukkan/ penghasilan karena sampah dimanfaatkan dengan baik dan bernilai guna (Mulasari, 2018). Dengan semakin banyaknya sampah yang berhasil direduksi dari sumbernya, maka akan semakin sedikit sampah 
volume sampah yang dibuang ke TPA (Saibah, 2018).

\section{SIMPULAN DAN SARAN}

Berdasarkan kegiatan pengabdian kepada masyarakat di Kelurahan Ngletih Kecamatan Pesantren Kota Kediri, dapat disimpulkan bahwa:

1. Terjadi peningkatan pemahaman masyarakat responden tentang jenis sampah, pemilahan sampah dan pengelolaan sampah.

2. Ada perbedaan rerata yang bermakna antara skor pengetahuan sebelum dan setelah dilakukan penyuluhan tentang sampah.

3. Penyuluhan yang telah dilakukan berhasil meningkatkan pengetahuan responden tentang sampah.

Adapun sarannya adalah kegiatan penyuluhan dan simulasi/ praktek/ demonstrasi tentang pengelolaan sampah perlu dilakukan secara berkesinambungan untuk menumbuhkan kesadaran dan partisipasi masyarakat dalam upaya mengurangi jumlah volume sampah dan menjaga kelestarian lingkungan. Selain itu juga perlu adanya kader yang dapat memberikan pendampingan dan pemantauan terhadap kegiatan pengolahan sampah yang dilakukan masyarakat.

\section{DAFTAR PUSTAKA}

Cundari, L., Arita, S., Komariah, L. N., Agustina, T. E., \& Bahrin, D. (2019). Pelatihan Dan Pendampingan Pengolahan Sampah Organik Menjadi Pupuk Kompos Di Desa Burai. Jurnal Teknik Kimia, 25(1).

Fadillah, I., Lutfienzy, A., El Kamil, F., Shalahuddin, M. S. M., Setiawan, I., \& Fikri, K. (2019). Perubahan Pola Pikir Masyarakat tentang Sampah melalui
Sosialisasi Pengolahan Sampah Organik dan Non Organik di Dusun Pondok, Kecamatan Gedangsari, Kab. Gunungkidul. Prosiding Konferensi Pengabdian Masyarakat, 1, 239-242.

Kurniati, E., Mirawati, M., Rudiyanto, R., Fitriani, A. D., Rengganis, I., \& Justicia, R. (2019). Implementasi Program Anak Peduli Lingkungan Melalui Kegiatan Memilah Sampah. Early Childhood: Jurnal Pendidikan, 3(1), 1-6.

Mulasari, S. A. (2018). Pengelolaan Limbah Pertanian dan Rumah Tangga Berbasis Masyarakat di Desa Nglegi Patuk Gunungkidul, Yogyakarta. Jurnal Pengabdian Pada Masyarakat, 3(2), 141146.

Saibah, B. R. A. M., Marlina, W. A., Faisal, R. F., Agestayani, A., Erizal, E., Susiana, S., ... \& Jauharry, J. (2018). Pengelolaan Dan Pengolahan Sampah Pada Masyarakat Sekitar Kampus 2 Unand, Payakumbuh. Jurnal Hilirisasi IPTEKS, 1(4b), 274-284.

Syachruddin, A. R., Mukhlis, M., \& Bachtiar, I. (2019). Pengelolaan Sampah Organik Dan Plastik Di UPS (Unit Pengolahan Sampah)

Di Kelurahan Ampenan Selatan Kota Mataram Provinsi NTB. Jurnal Pendidikan dan Pengabdian Masyarakat, 2(2).

www.kompasiana.com. Ecobrick, Solusi Sederhana Yang Mampu Selamatkan Dunia. 13 Juli 2018. Diakses 3 Oktober 2019 jam $\quad 13.45$ WIB. 